\title{
Evaluation of analgesic efficacy of the combination of fentanyl with low dose bupivacaine $v s$ ropivacaine using patient controlled epidural analgesia for control of labour pain- an indian perspective!
}

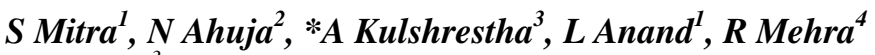 \\ Professor $^{l}$, Assistant Professor ${ }^{3}$, Department of Anaesthesia and Intensive care, Associate Professor ${ }^{3}$, \\ Department of Obstetrics and Gynaecology, Government Medical College and Hospital, Senior \\ Resident ${ }^{2}$, Department of Anaesthesia and Intensive Care, Postgraduate Institute of Medical \\ Education and Research, Chandigarh, India.
}

*Corresponding author: kulshi_20@ rediffmail.com

\begin{abstract}
Introduction: We undertook this study to compare the analgesic efficacy of $0.1 \%$ bupivacaine and $0.1 \%$ ropivacaine with fentanyl using patient controlled epidural analgesia.

Materials and methods: 60 parturients of $\geq 36$ weeks of gestation with cephalic presentation in spontaneous labour with cervical dilatation $\leq 5 \mathrm{cms}$ and baseline pain score of $\geq 30$ on visual analogue scale (VAS), were enrolled in the study. Group I received $10 \mathrm{ml}$ bolus of $0.1 \%$ bupivacaine with fentanyl $2 \mu \mathrm{g} / \mathrm{ml}$ while Group II received $10 \mathrm{ml}$ bolus of $0.1 \%$ ropivacaine with fentanyl $2 \mu \mathrm{g} / \mathrm{ml}$ followed by patient controlled epidural analgesia (PCEA) using PCA pump. The primary outcome measured was analgesic efficacy using VAS.
\end{abstract}

Results: VAS scores during first and second hour were found to be significantly lower in Group 1 as compared to Group 2 (Figure 1) with a significant difference from their respective baselines. Group II showed a statistically higher total drug consumption and number of boluses used $(62.33 \pm 26.6$ vs $48.47 \pm 16.7$ and1.40 \pm 0.8 vs $2.00 \pm 0.8$ respectively) as compared to group I (Table 2) (Figure 3). The motor block showed a statistically significant difference at $4^{\text {th }}, 5^{\text {th }}$ and $6^{\text {th }}$ hours between the two groups (Figure 4 ).

Conclusion: The present study demonstrated that $0.1 \%$ ropivacaine or $0.1 \%$ bupivacaine with fentanyl $2 \mu \mathrm{g} / \mathrm{ml}$ used during labour analgesia by PCEA were equally effective for controlling the labour pain with more total drug consumption and less motor blockade associated with $0.1 \%$ ropivacaine as compared to $0.1 \%$ bupivacaine.

Keywords: Labour Analgesia, patient-controlled epidural analgesia (PCEA), bupivacaine, ropivacaine.

\section{Introduction}

Providing safe and effective analgesia for pain relief during labour has been a constant challenge for the anaesthesiologists. ${ }^{1}$ Neuraxial epidural analgesia has been seen to completely relieve the pain of labour and is the 'gold standard' for labour analgesia. ${ }^{2,3}$ From among the vast array of local anaesthetics available, ropivacaine and bupivacaine are the most commonly used and approved by the Food and Drug Authority (FDA) for use in obstetric analgesia and anaesthesia. ${ }^{5}$ The combination of a local anaesthetic with a lipid-soluble opioid allows the use of lower doses of each agent, thus minimizing undesirable side effects. ${ }^{6}$ The use of low concentrations of ropivacaine along with opioids have found to be effective in labor analgesia with minimal motor blockade. We conducted a study to evaluate and compare the analgesic efficacy of $0.1 \%$ bupivacaine with fentanyl $2 \mu \mathrm{g} / \mathrm{ml}$ and $0.1 \%$ ropivacaine with fentanyl $2 \mu \mathrm{g} / \mathrm{ml}$ solutions using PCEA.

\section{Materials and methods}

After approval by the institutional ethics committee and obtaining informed consent from the patients, a total of 68 parturients with age more than 18 years, belonging to ASA grade I and II, presenting with cephalic presentation at $\geq$ 36 weeks of gestation in early spontaneous labour with cervical dilatation of $\leq 5 \mathrm{cms}$, having baseline pain score $>30$ on VAS and patients requesting for labour analgesia, were selected for the study. The patients who refused 
labour analgesia, who had received parenteral opioids in last 3 hours, patients on chronic pain medications, non-cephalic presentations, having documented allergy to the study drugs and patients with general contraindications for neuraxial anaesthesia, were excluded from the study.

The study was prospective, randomized and double blind. With the power of the study as $80 \%$ and alpha error of $0.05,{ }^{7}$ a total of 60 patients were calculated as appropriate sample size. The patients were randomized into 2 groups by using coded and sealed opaque envelopes using computer generated random number tables to receive one of the following regimens:

Group I - parturients received $0.1 \%$ bupivacaine with fentanyl $2 \mu \mathrm{g} / \mathrm{ml}$, as $10 \mathrm{ml}$ initial bolus.

Group II - parturients received $0.1 \%$ ropivacaine with fentanyl $2 \mu \mathrm{g} / \mathrm{ml}$, as $10 \mathrm{ml}$ initial bolus.

The patients as well as the primary investigator who made the various observations after the epidural catheter placement were blinded to the group allocation of the patients. There was a provision of patient controlled epidural boluses of $5 \mathrm{ml}$ of the respective drugs with a lockout interval of $12 \mathrm{~min}$ and a continuous background infusion of $5 \mathrm{ml} /$ hour in both the groups using PCA pump. For insertion of the epidural catheter, the patient was taken to the clean labour room (CLR) operation theatre and intravenous access was obtained and the patient preloaded with 500-1000 ml of Ringer lactate solution. Multichannel (Datex Light, Helsinki) monitors were attached and baseline heart rate (HR), non-invasive blood pressure (NIBP) and oxygen saturation $\left(\mathrm{SpO}_{2}\right)$ was obtained. A baseline visual analog pain score (VAS based on a $0-100 \mathrm{~mm}$ scale, $0 \mathrm{~mm}=$ no pain and $100 \mathrm{~mm}$ $=$ worst pain imagined) was also obtained. The patient was monitored for HR, NIBP, motor block and $\mathrm{SpO}_{2}$ every 5 minutes for 20 minutes after bolus and thereafter hourly throughout the study period. Epidural injection was given using midline technique with disposable $18 \mathrm{G}$ Tuohy needle with loss of resistance technique. The patient was observed for $20 \mathrm{~min}$ and monitored continuously for HR, NIBP, pain score, time for the onset of action $(\mathrm{VAS}<30$ ) and modified Bromage score $^{8}$ for motor power in CLR OT before shifting the patient to labour room for monitoring of the mother and foetus during the course of labour. These observations were made by primary investigator who was blinded to the group allocation of the patients. In the event of an inadvertent intravascular or dural puncture by the epidural needle or catheter, the parturient was excluded from the study and managed according to the departmental protocols. The other variables measured were total consumption of anaesthetic drugs during the course of labour, time of onset of sensory block, any side-effects like nausea and vomiting, duration of second stage of labour, mode of delivery and Apgar scores at 1 and 5 minutes. Hypotension was defined as a decrease in SBP of more than $20 \%$ below baseline, and was treated with left uterine tilt, IV fluids, and vasopressors (5mg ephedrine or $50 \mu \mathrm{g}$ phenylephrine IV) as necessary. Overall maternal satisfaction score with labour analgesia was assessed and documented.

\section{Statistical analysis}

The observations were analyzed using Statistical Package for Social Sciences (SPSS), by the following analytical tests. The data about the age, height, weight, cervical dilatation, onset time, bolus requirement, duration of $2^{\text {nd }}$ stage labour, Apgar scoring, total drug consumption and maternal satisfaction of the parturients in the two groups was analyzed by the independent student's t-test. For the VAS scores and the motor blockade, the overall difference between the two groups was analyzed using the MannWhitney test, whereas, the intragroup difference from their respective baselines was analyzed using the Wilcoxon Signed Rank test. For analyzing the data regarding the parturients' HR, NIBP and fetal heart rate, intergroup analyses at each time point was done by independent student's t-test. Whereas, the within group analyses was done using one-way ANOVA (post-hoc by Dunnett t-test). The difference between the modes of delivery in the two groups was analyzed using the Chi-square test.

\section{Results}

A total of sixty patients, 30 in each group, completed the study. The demographic variables including age, height and weight among the two groups were comparable (Table 1)

Table 1: Comparison of demographic characteristics and other parameters

\begin{tabular}{|l|l|l|l|}
\hline & Group I & Group II & p value \\
\hline $\begin{array}{l}\text { Age in yrs (Mean } \\
\pm \text { SD) }\end{array}$ & $26.03 \pm 3.11$ & $25.90 \pm 2.38$ & 0.85 \\
\hline $\begin{array}{l}\text { Height cms } \\
\text { (Mean } \pm \text { SD) }\end{array}$ & $158.17 \pm 3.32$ & $158.33 \pm 2.57$ & 0.82 \\
\hline
\end{tabular}




\begin{tabular}{|c|c|c|c|c|c|c|c|}
\hline $\begin{array}{l}\text { Weight kgs } \\
\text { (Mean } \pm \text { SD) }\end{array}$ & \multicolumn{3}{|c|}{$63.10 \pm 3.85$} & \multicolumn{3}{|c|}{$64.07 \pm 3.76$} & 0.33 \\
\hline $\begin{array}{l}\text { Parity (Gravida) } \\
(\%)\end{array}$ & $\begin{array}{l}\mathrm{GI} 29 \\
(96.7)\end{array}$ & \multicolumn{2}{|c|}{ GII 1(3.3) } & $\begin{array}{l}\mathrm{GI} 28 \\
(93.3)\end{array}$ & \multicolumn{2}{|c|}{ GII 2(6.7) } & 0.78 \\
\hline $\begin{array}{l}\text { Physical Status } \\
\text { (ASA) } \%)\end{array}$ & $\begin{array}{l}\text { I: } 26 \\
(86.7)\end{array}$ & \multicolumn{2}{|c|}{ II: 4 (13.3) } & $\begin{array}{l}\text { I: } 25 \\
(83.3)\end{array}$ & \multicolumn{2}{|c|}{ II: 5 (16.7) } & 0.62 \\
\hline $\begin{array}{l}\text { Cervical } \\
\text { Dilatation }(\mathrm{cms})\end{array}$ & \multicolumn{3}{|c|}{$4.00 \pm 0.69$} & \multicolumn{3}{|c|}{$3.83 \pm 0.69$} & 0.35 \\
\hline $\begin{array}{l}\text { Duration of IInd } \\
\text { stage of labor } \\
\text { (mins) }\end{array}$ & \multicolumn{3}{|c|}{$64.44 \pm 28.27$} & \multicolumn{3}{|c|}{$61.923 \pm 22.51$} & 0.72 \\
\hline $\begin{array}{l}\text { Mode of delivery } \\
\mathrm{n}(\%)\end{array}$ & $\begin{array}{l}\text { Norma } \\
1 \\
23 \\
(76.7)\end{array}$ & $\begin{array}{l}\text { Forc } \\
\text { eps } \\
2 \\
(6.7)\end{array}$ & 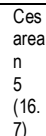 & $\begin{array}{l}\text { Norm } \\
\text { al } \\
23 \\
(76.7)\end{array}$ & $\begin{array}{l}\text { Force } \\
\text { ps } \\
3(10)\end{array}$ & $\begin{array}{l}\text { Cesare } \\
\text { an } \\
4 \\
(13.3)\end{array}$ & 0.88 \\
\hline $\begin{array}{l}\text { Overall Maternal } \\
\text { Satisfaction } \\
\text { Score }\end{array}$ & \multicolumn{3}{|c|}{$84.93 \pm 7.02$} & \multicolumn{3}{|c|}{$81.83 \pm 6.92$} & 0.90 \\
\hline $\begin{array}{l}\text { APGAR Scores } \\
\text { (Mean } \pm \text { SD) }\end{array}$ & $\begin{array}{l}1 \min \\
8.63 \pm \\
0.61\end{array}$ & \multicolumn{2}{|c|}{$\begin{array}{l}5 \min \\
8.93 \pm 0.25\end{array}$} & $\begin{array}{l}1 \mathrm{~min} \\
8.47 \pm \\
1.35\end{array}$ & \multicolumn{2}{|c|}{$\begin{array}{l}5 \min \\
8.90 \pm 0.30\end{array}$} & 0.55 \\
\hline $\begin{array}{l}\text { Nausea \& } \\
\text { Vomiting n (\%) }\end{array}$ & \multicolumn{3}{|l|}{$3(10)$} & \multicolumn{3}{|l|}{$1(3.3)$} & 0.57 \\
\hline
\end{tabular}

VAS scores during first and second hour were found to be highly significant between the two groups with a significant difference from their respective baselines on intragroup comparison. (Table 2) The group II (ropivacaine+ fentanyl) showed a statistically higher total drug consumption and number of boluses used (62.33 \pm 26.6 vs $48.47 \pm 16.7$ and $1.40 \pm 0.8$ vs $2.00 \pm$ $0.8, \mathrm{p}<0.05$ respectively) as compared to group I (bupivacaine + fentanyl) and similar results were obtained with the total number of boluses used $(p<0.05)$. (Table 3$)$ The time of onset of action of local anaesthetic drugs i.e. time for VAS $\leq 30$ was not statistically significant between the two groups $(10.97 \pm 2.470 \mathrm{~min}$ for bupivacaine and $11.40 \pm 2.884 \mathrm{~min}$ for ropivacaine).

The motor block showed a statistically significant difference at $4^{\text {th }}, 5^{\text {th }}$ and $6^{\text {th }}$ hours between the two groups with bupivacaine group showing a significant motor blockade.

Table 2: Comparison of mean VAS scores in the two groups

\begin{tabular}{|c|c|c|c|}
\hline Time & $\begin{array}{l}\text { Group I } \\
\text { (Median VAS) }\end{array}$ & $\begin{array}{l}\text { Group II } \\
\text { (Median VAS) }\end{array}$ & $\begin{array}{l}\mathrm{p}- \\
\text { value }\end{array}$ \\
\hline 0 Min & $89(85.5-91)$ & $87(79-92)$ & 0.325 \\
\hline 5 Min & $48(34-54.5)$ & $43.5(36-50.5)$ & 0.505 \\
\hline 10 Min & $15(9.5-23.25)$ & $15.5(10.75-21)$ & 0.745 \\
\hline $15 \mathrm{Min}$ & $7.5(0-14.25)$ & $8(5-15.25)$ & 0.554 \\
\hline $20 \mathrm{Min}$ & $6(0-13.5)$ & $8(2.25-15)$ & 0.394 \\
\hline $1 \mathrm{Hr}$ & $9(4.5-16)$ & $18(11-24)^{*}$ & 0.000 \\
\hline $2 \mathrm{Hr}$ & $17(13-24)$ & $20(19.5-39)^{n}$ & 0.013 \\
\hline $3 \mathrm{Hr}$ & $26(17-28)$ & $24(19-29.75)$ & 0.840 \\
\hline $4 \mathrm{Hr}$ & $23.5(18.25-31.75)$ & $22(18-28.5)$ & 0.625 \\
\hline $5 \mathrm{Hr}$ & $19(18-34)$ & $26(18.5-32)$ & 0.766 \\
\hline $6 \mathrm{Hr}$ & $26(21.5-37.25)$ & $27.5(18.75-31)$ & 0.722 \\
\hline $7 \mathrm{Hr}$ & - & $25(21.5-36)$ & 0.696 \\
\hline $8 \mathrm{Hr}$ & - & $36.5(31-39)$ & 0.617 \\
\hline
\end{tabular}

$*$ p value $<0.05$ : statistically significant

Table 3: Comparison of total drug consumption and total boluses required in the two groups

\begin{tabular}{|l|l|l|}
\hline Group & $\begin{array}{l}\text { Total drug } \\
\text { consumed(ml) } \\
\text { (Mean } \pm \text { S.D.) }\end{array}$ & $\begin{array}{l}\text { Total No. of } \\
\text { boluses } \\
\text { (Mean } \pm \text { S.D.) }\end{array}$ \\
\hline Group I & $48.47 \pm 16.735$ & $1.40 \pm 0.894$ \\
\hline Group II & $62.33 \pm 26.694$ & $2.00 \pm 0.845$ \\
\hline p- value & $0.019^{\star}$ & $0.010^{\star}$ \\
\hline
\end{tabular}

$* \mathrm{p}$ value $<0.05$ : significant

The mean maternal heart rate, systolic blood pressure, diastolic blood pressure and the fetal heart rate were found to be comparable and statistically non-significant at different time points between the two groups ( $\mathrm{p}>0.05$ )

\section{Discussion}

In the present study epidural ropivacaine and bupivacaine has been used in the concentration of $0.1 \%$ along with $2 \mu \mathrm{g} / \mathrm{ml}$ fentanyl because the earlier studies comparing $0.25 \%$ ropivacaine and $0.25 \%$ bupivacaine in labouring women of mixed parity suggested that these drugs were associated with increased motor blockage. Later, studies maintaining labour analgesia with lower concentration of bupivacaine and ropivacaine $(0.0625-0.1 \%)$ combined with fentanyl $2 \mu \mathrm{g} / \mathrm{ml}$ suggested that dilute local anaesthetic solutions with opioids for labour PCEA results in less local anaesthetic consumption and motor block without compromising labour analgesia. ${ }^{10}$ Ropivacaine has been recently made available in India for clinical use, there are limited reports comparing ropivacaine and bupivacaine for labour analgesia by PCEA. In order to reduce bias, our study was prospective, randomized, and double blinded.

In the present study, the mean VAS score before institution of epidural analgesia was $87.60 \pm$ 4.825 in the bupivacaine group and $85.37 \pm$ 7.416 in the ropivacaine group. So women on the request of epidural analgesia were given the initial dose of $10 \mathrm{ml}$ of study solution as the test dose. Following the administration of the drug there was significant pain relief $(\mathrm{VAS}<30)$ within the first 10-12 minutes in patients of both the groups without any statistical significance in the onset time of both the drugs $(10.97 \pm 2.470$ min for bupivacaine and $11.40 \pm 2.884 \mathrm{~min}$ for 
ropivacaine). Maintenance of PCEA was started after the loading dose as described. There was significant difference in the VAS scores at 1 and 2 hours between the two groups with bupivacaine group showing significantly lower mean VAS scores. However, the overall difference between the mean VAS score during treatment (i.e. from the time of the epidural loading dose until delivery) between the two groups was statistically non-significant.

The various studies in past demonstrated that the use of dilute local anaesthetic solutions with opioids for labour PCEA results in less local anaesthetic consumption and motor block without compromising labour analgesia. ${ }^{11}$ So in our study dilute concentrations of local anaesthetics along with opioids were taken as the study solutions. Ropivacaine has been reported to be $40 \%$ less potent than bupivacaine. However studies using dilute solutions $(0.0625 \%-0.1 \%)$ of ropivacaine along with opioid showed equal analgesic efficacy in labour with reduction in the total consumption of drug. ${ }^{12}$ So equal concentrations of both the local anaesthetic solutions were selected in the present study.

Pirbudak et al. ${ }^{9}$ compared the efficacy of ropivacaine $0.05 \%$ and bupivacaine $0.05 \%$, both combined with fentanyl $1.5 \mu \mathrm{g} / \mathrm{ml}$ in 40 nulliparous patients to provide analgesia in labour. The results of this study where the VAS score did not increase with the progression of labour, are in line with our results. Similar results were reported by Halpern et $\mathrm{al}^{12}$ and Lee et $\mathrm{al}^{13}$ who compared $0.1 \%$ solutions of ropivacaine and bupivacaine and also Beilin et al who compared still lower concentrations $(0.0625 \%)$ of both the local anaesthetics. ${ }^{14}$ The findings of our study were thus, consistent with the previous studies.

We found a significantly lower mean dose of bupivacaine used as compared to the mean dose of ropivacaine which was similar to the study by Fischer C. etal. ${ }^{15}$ who observed that during the second stage, drug consumption was significantly greater with ropivacaine than with bupivacaine $(30.4 \mathrm{ml} / \mathrm{h}$, range $0-187$, vs. 22.2 $\mathrm{ml} / \mathrm{h}$, range $0-312$ ). The mean duration of second stage was comparable in both the groups. According to the ACOG guidelines, none of the women in either group had prolonged second stage. The results of our study coincided with the study by Lee et al and Beilin et al. ${ }^{14,15}$ The motor blockade among the two groups was significantly higher in the $4^{\text {th }}, 5^{\text {th }}$ and $6^{\text {th }}$ hours of labour. Our results were consistent with other trials which reported statistically lower incidence of motor block in the ropivacaine group compared to the bupivacaine group. ${ }^{13} \mathrm{In}$ this study there were more parturients without motor block in the ropivacaine group than in the bupivacaine group, although this difference was neither statistically significant nor clinically meaningful.

In conclusion, the present study demonstrated that $0.1 \%$ ropivacaine or $0.1 \%$ bupivacaine with fentanyl $2 \mu \mathrm{g} / \mathrm{ml}$ used during labour analgesia by PCEA were equally effective for controlling the labour pain, without any significant difference in mode of delivery, side effects or neonatal outcome. The strength of this study is its randomized double blind, prospective study design. . The caveat of the present study is a short observation study period. In future, longer observation period could throw further light on the efficacy of low dose ropivacaine and bupivacaine in combination with fentanyl on the pain relief and foetal and maternal outcome of the parturients.

\section{References}

1. Pandya S.T. Labour analgesia: Recent advances. Indian J Anaesth 2010; 54: 400-8. http://dx.doi.org/10.4103/0019-5049.71033 PMid:21189877 PMCid:PMC2991649

2. Vincent RD, Chestnut DH. Epidural analgesia during labour. American academy of family physicians [Internet] 1998. (accessed on 2010 Nov 7) Available from : http://www.aafp.org/afp/981115ap/vincent.html

3. Stark MA. Exploring women' preferences for labour epidural analgesia. J PerinatEduc 2003; 12:16-21. PMid:17273336 PMCid:PMC1595147

4. Van de Vyver M, Harper S, Joseph G. Patientcontrolled epidural analgesia versus continuous infusion for labour analgesia: a meta-analysis.
BrJAnaesth 2002; 89: 459-65. http://dx.doi.org/10.1093/bja/89.3.459

5. Haire D. FDA approved obstetrics drugs: their effects on mother and baby [Internet]. (accessed on 2011 April 5) Available from: http://www.aimsusa.org/obstetricdrugs.htm.

6. Polley LS, Columb MO Wagner DS, Naughton NN. Dose-dependent reduction of the minimum local analgesic concentration of bupivacaine by sufentanil for epidural analgesia in labor. Anesthesiology 1998; 89: 626-32. http://dx.doi.org/10.1097/00000542-199809000- 
Mitra et al. Sri Lankan Journal of Anaesthesiology: 23(2):61-65(2015)

$\underline{00011}$

PMid:9743398

7. Muir HA, Writer D, Douglas J, Weeks S, Gambling D, Macarthur A. Double-blind comparison of epidural ropivacaine $0.25 \%$ and bupivacaine $0.25 \%$, for the relief of childbirth pain. Can J Anesth. 1997; 44: 599-604. http://dx.doi.org/10.1007/BF03015442 PMid:9187778

8. Dutta DC. Normal labour. In: Text book of obstetrics, 7th ed. HiralalKonar New Central Book Agency, Calcutta 2011:113-44. PMid:22654305 PMCid:PMC3136664

9. Pirbudak L, Tuncer S, Kocoglu H, Goksu S, Celik C. Fentanyl added to bupivacaine $0.05 \%$ or ropivacaine $0.05 \%$ in patient controlled epidural analgesia in labour. Eur J Anaesthesiol 2002; 19: 271-5.http://dx.doi.org/10.1097/00003643200204000-00004

PMid:12074416

10. Halpern S, Beilin Y. Ropivacaine versus bupivacaine for epidural labor analgesia. Anesth and Analg 2010; 111: 482-87. http://dx.doi.org/10.1213/ANE.0b013e3181e3a0 $\underline{8 \mathrm{e}}$ PMid:20529986

11. Polley LS, Columb MO, Naughton NN, Wagner DS, Van de Ven CJM. Relative analgesic potencies of ropivacaine and bupivacaine for epidural analgesia in labor. Anesthesiology 1999; 90:944 -50. http://dx.doi.org/10.1097/00000542-199904000$\underline{00003}$

PMid:10201661

12. Halpern SH, Breen TW, Campbell DC, Muir HA, Kronberg J, Nunn R, et al. A multicenter, randomized, controlled trial comparing bupivacaine with ropivacaine for labor analgesia. Anesthesiology 2003; 99: 1431-35. http://dx.doi.org/10.1097/00000542-20030600000020

13. Lee BB, NganKee WD, Ng FF, Lau TK, Wong EL. Epidural infusions of ropivacaine and bupivacaine for labor analgesia: A randomized, double-blind study of obstetric outcome.AnesthAnalg 2004; 98:1145-52. http://dx.doi.org/10.1213/01.ane.0000103264.71 747.0f

14. Beilin Y, Guinn NR, Bernstein HH, Zahn J, Hossain S, Bodian CA. Local anaesthetics and mode of delivery: bupivacaine versus ropivacaine versus levobupivacaine. AnesthAnalg. 2007; 105:756-63. http://dx.doi.org/10.1213/01.ane.0000278131.73 472.f4

PMid:17717236

15. Fischer C., Blanie P., Jaouen E., Vayssiere C., Kaloul I., Coltat J.C. Ropivacaine, $0.1 \%$, Plus Sufentanil $0.5 \mu \mathrm{g} / \mathrm{ml} \&$ versus Bupivacaine, 0.1 $\%$, Plus Sufentanil $0.5 \mu \mathrm{g} / \mathrm{ml}$ for Using Patient- controlled Epidural Analgesia for labor. Anesthesiology 2000; 92:1588-93. http://dx.doi.org/10.1097/00000542-200006000$\underline{00015}$

PMid: 10839907 